\title{
Future city - challenges and opportunities for water-sensitive sustainable cities, in India
}

\author{
Vandana Pusalkar ${ }^{*}$ Vimala Swamy ${ }^{2}$ and Anand Shivapur ${ }^{3}$ \\ 1. Visvesvaraya Technological University, Belgavi, Karnataka, India \\ 2. Reva University, Banglore, Karnataka, India. \\ 3 Visvesvaraya Technological University, Belagavi, Karnataka, India
}

\begin{abstract}
Rapid urbanization, depleted resources, imbalance in urban hydrologic cycle, tremendous pressure on ecological functions, unhygienic and unhealthy environment is the scenario in almost all Indian cities. Water resources in the urban areas are fast depleting while the demand for the same is fast growing. Now more than ever before, water resources face threats from climate change, population growth, aging infrastructure, declining revenues, and a variety of other localized challenges. The challenge is to find ecologically sustainable, socially justified, economically viable, culturally transferable, and technological and managerial innovations which are appropriate to meet the needs of the future generations i.e. sustainable urban development. What is sustainable development? Detail study of sustainable development goals especially related to water, various recent trends of city development at major parts of world, from water perspective like Water- sensitive city, Water-wise city. Water-centric sustainable community can prove to be an ideal model of city development that will be truly sustainable with full focus on ecological balance so that social and economical sustainability also can be achieved.
\end{abstract}

Keywords: - Sustainable development, water- sensitive city, water- wise city, water centric sustainable community.

\section{Introduction}

Cities have multiplied and expanded rapidly worldwide over the past two centuries. Urban centers having world's economic activities, utilizes maximum natural resources and generate most waste and pollution (1). Since ancient times, cities started as walled villages or settlements on the bank of rivers, streams. Without water, life in the cities could not be sustained. Water also provides for cleaning and hygiene, transportation, irrigation of crops and gardens, defense and transportation (2). But, what is the urban water scenario all over the world? Especially in developing countries, like India. In India almost all rivers flowing through the cities are getting polluted and converted to drainage carrying corridors i.e. nallahs (polluted water stream).

As stated by almost all professionals like urban planners, urban designers, landscape designers, environment engineers and scientists that urban water infrastructure, its planning and management needs to be changed drastically (2). The conceptual models employed in most cities have not changed much since Roman times. They comprise rapid-conveyance piped water to carry away human and industrial wastes for disposal. Managing water quality, both for potable and disposal purposes, is generally accomplished by removing contaminants at the beginning or end of the pipe. Historical paradigm of municipal sewerage and drainage system was adopted for mainly two purposes, 1) Public health and hygiene and 2) Prevent flooding (3). One of the most pervasive challenges is the alteration of the urban water cycle (3)

\subsection{Methodology}

This review paper is to study, the consequences of urbanization, and other economic development activities on flowing water bodies in Indian cities. How this urban water scenario can be transformed to make them sustainable cities? In first part of the paper, an exhaustive background study regarding number of challenges and reasons behind this unsustainable situation due to polluted urban rivers is explored, and in second part of the paper, case studies have been done to study various approaches worldwide to restore the degraded urban rivers, as the problem is complex and multifaceted.

\section{Challenges in water sector}


Unprecedented urbanization and industrialization imposing environmental degradation on such a vast scale, that results into polluted water bodies inside cities putting extreme pressures on urban local bodies to make available and manage safe and clean water supply to growing population (4). The challenge is to supply quality water as per C.P.C.B. (Central Pollution Control Board, India) standards to each and every individual as per their needs by keeping in mind ecological sustainability as a main concern (4).

\subsection{Water: International, national scenario}

The world water council says, " There is a water crisis today. But the crisis is not about having too little water to satisfy our needs. It is a crisis of poor water management that affects billions of people and the environment suffer badly". (5)

Out of total available water resources on Earth, $97.5 \%$ water is in oceans, $2.5 \%$ fresh water $(1.5 \%$ water trapped in glaciers, $0.9 \%$ ground water and $0.1 \%$ surface water) (6). Extensive use of water resources for various purposes like domestic, agricultural, industrial, etc. leads to water scarcity. (7). It is persistent due to deterioration of flowing (Rivers/Streams) or stagnant (lakes) water bodies as various pollutants mixed with fresh water. All professionals think that, water reuse is the only solution to reduce this water scarcity. Degraded quality of water as a result of impact of socio-economical systems is the main concern of urban local bodies at city level. Water scarcity is a quality problem rather than quantity (5). In Table:-1 Institutional challenges in water sector are catagorised with respect to urban water governance in India.

Table 1:- Institutional challenges and opportunities in water sector (8)

\begin{tabular}{|c|c|c|}
\hline Sr.No & \multicolumn{2}{|c|}{ Institutional challenges and opportunities } \\
\hline 1 & Planning and co-ordination & $\begin{array}{l}\text { Planning is not co-ordinated. No inter-departmental collaborative } \\
\text { innitiatives right from central level to local level. No long-term solutions } \\
\text { and lacunas in implimentation of it in flexible manner. }\end{array}$ \\
\hline 2 & Finance management & $\begin{array}{l}\text { Lack of innovative financially viable solutions, conventional cost intensive } \\
\text { centralised approach.Inefficient to manage the situation. }\end{array}$ \\
\hline 3 & $\begin{array}{l}\text { Acts, bye-laws, rules and } \\
\text { regulations }\end{array}$ & $\begin{array}{l}\text { key drivers how organizations works to strategize, plan, budget, and } \\
\text { implement projects }\end{array}$ \\
\hline 4 & Community participation & Ensure community participation and development of active citizen,s forum. \\
\hline 5 & Culture/Knowledge/Capacity & $\begin{array}{l}\text { Cultural changes needed with appropriate knowledge of urban water } \\
\text { management is challenging and results can be unpredectable. }\end{array}$ \\
\hline
\end{tabular}

\subsection{How climate change affects cities?}

On one side, cities are playing main role in economic developments, but in due course of time on the other side human well being in cities is very neglected part. Now climate change will have direct or gradual impact on both these roles. The direct impact may be in the form of sudden shocks like, storms, typhoons, heat waves and floods or gradual impact such as sea level rise, temperature increase and whether changes, etc (9).

\subsubsection{Resilience and Urban Ecosystem services}

The capacity of water system to sustain and adopt to the adverse effects and retain its basic identity, function and performance is called resilience. (10). Same can be true to the context of cities. The capacity of cities to sustain and adopt to the adverse effects of environmental degradation, ecological crisis, water crisis and climate change, global warming, etc. and still try to retain its basic identity, function and performance is called resilient city. (11).

"Urban ecosystem services are generated in a diverse set of habitats, including: green spaces, such as parks, urban forests, cemeteries, vacant lots, gardens and yards, campus areas, landfills; and blue spaces, including streams, lakes, ponds, artificial swales, and storm water retention ponds" (12).

\subsubsection{Urban water and human health and cities (urban) health}

Since historical times nobody denies the relationship of cities health and water resource quality. (13). Urban water management and Water health management plays a major role in protecting the health of urban populations worldwide (14). In 1984 the Healthy Cities movement originated in Toronto, Canada. To protect health of citizens, water health plays major role which is accepted and agreed by WHO (World Health Organization) and hence, promoted healthy cities movement worldwide since 1986.

\section{Discussions}

Impact posed by economic development activities on water systems are getting more and more complex today that creating chaotic condition in cities. As a result, 
whatever actions taken against nature at local level has directly or indirectly adverse effects on the regional and global level. (15). To assess sustainable development goals related to water, needs knowledge of urban Hydrological Cycle and how its imbalance have repercussions both at local and global level (15).

\subsection{Sustainable Development goals, 2015}

Efforts to meet human water needs at local scales may cause negative environmental impact and stress on the water system at regional and global scales. Hence, assessing Sustainable Development Goals (SDGs) targets requires broad and in-depth knowledge of the global to local dynamics of water availability and use (16).

Superimposing the different elements of global change, the question thus arises of how sustainable human development can be ensured while safeguarding earth's vital life-support system on which the welfare of current and future generation depends? As stated in the first sentence of the World Water Development Report 2015, "water is at the core of sustainable development and the latter is strongly connected to the availability and access to sufficient quantity and quality of water for the preservation of healthy ecosystems and is critical for socio-economic and human development" (17). Sustainable Development Goals (SDG), SDG61and SDG112, are fully empasised on sustainable urban water management for resilient cities (18). To achieve this we need to harness the power of collaboration: a new paradigm for water management infrastructures and policies, enabled by new governance that spurs broader collaboration, motivates stakeholder engagement and active citizenship involvement as shown in table 2.

\subsection{A sustainable water vision (Opportunities)}

A sustainable urban water vision, as part of a resilient city vision, enables people to work together at different scales and across disciplines. It enables the political will needed to invest in long term measures. It provides consistency beyond political cycles. The International Water Association published final draft "Principles for waterwise cities". In this document, they determined to play a decisive role in making it possible, inspiring a shared vision of sustainable urban water as shown in table 3 .

\subsection{Water Sensitive Eco-cities}

In Year 1896, Ebenezer Howard launched the garden city movement in his book 'Garden Cities of Tomorrow' in which he describes how cities can be planned with green open spaces to line with nature without much impacting it. (19). Cities thus have increasingly large "ecological footprints" Its definition was coined by Register (1987) as "a sustainable city, or eco-city is a city designed with consideration of environmental impact, inhabited by people dedicated to minimization of required inputs of energy, water and food, and waste output of heat, air pollution - $\mathrm{CO} 2$, methane, and water pollution". Global warming, climate change and other environmental externalities of haphzard growth made compulsory to all countries to promote eco-cities and resilient cities (19). To develop sustainable water-centric eco-cities, water management different strategies at different level can be adopted as per table no. 4

Table 2:-The four level of action (8)

\begin{tabular}{|c|c|c|c|}
\hline $\begin{array}{l}\text { Level A. Regenerative } \\
\text { Water Services for all: }\end{array}$ & $\begin{array}{l}\text { Level B. Water Sensitive } \\
\text { Urban Design: }\end{array}$ & $\begin{array}{ll}\text { Level C.Watershed } \\
\text { management }\end{array}$ & $\begin{array}{l}\text { Level D. } \\
\text { Communities: }\end{array}$ \\
\hline $\begin{array}{l}\text { Rejuvenate } \\
\text { bodies and their } \\
\text { ecosystems to protect } \\
\text { the water sources. }\end{array}$ & $\begin{array}{l}\text { Plan and implement urban } \\
\text { design ensuring rejuvenating } \\
\text { water services. cleaner } \\
\text { waterways, benefiting } \\
\text { ecosystems and people }\end{array}$ & $\begin{array}{l}\text { Secure the water resource } \\
\text { plan for drought mitigation } \\
\text { strategies by sharing water } \\
\text { for agriculture, industry } \\
\text { and energy sectors }\end{array}$ & $\begin{array}{l}\text { Citizens involved in the } \\
\text { progressive urban water } \\
\text { vision. opportunities } \\
\text { (resource recovery, future } \\
\text { resources, well-being). }\end{array}$ \\
\hline $\begin{array}{l}\text { ion in water and } \\
\text { useage. }\end{array}$ & $\begin{array}{l}\text { Design urban spaces to } \\
\text { reduce flood risks. }\end{array}$ & $\begin{array}{l}\text { Protect the quality of the } \\
\text { water resource }\end{array}$ & $\begin{array}{l}\text { Policy makers enable the } \\
\text { implementation }\end{array}$ \\
\hline & $\begin{array}{l}\text { to enable regenerative water } \\
\text { services. }\end{array}$ & & Trans-disciplinary planning \\
\hline $\begin{array}{l}\text { Recover energy from } \\
\text { water Recycle nutrients } \\
\text { or organic matter from } \\
\text { water }\end{array}$ & $\begin{array}{l}\text { Urban design strategies } \\
\text { minimise their impact on } \\
\text { water pollution: }\end{array}$ & $\begin{array}{l}\text { Plan for extreme events, } \\
\text { including flooding by } \\
\text { managing flow regimes in } \\
\text { rivers }\end{array}$ & $\begin{array}{l}\text { Experts from } \\
\text { Professions }\end{array}$ \\
\hline Increase modularity & $\begin{array}{l}\text { Enhance liveability } \\
\text { visible water }\end{array}$ & $\begin{array}{l}\text { Investing flood warning } \\
\text { systems. }\end{array}$ & $\begin{array}{l}\text { Water wise policies and } \\
\text { financing }\end{array}$ \\
\hline $\begin{array}{l}\text { Use a systems approach } \\
\text { integrated with other } \\
\text { services }\end{array}$ & $\begin{array}{l}\text { improving social and urban } \\
\text { amenities by building green } \\
\text { infrastructure }\end{array}$ & $\begin{array}{l}\text { on in the basin to } \\
\text { e flash floods }\end{array}$ & $\begin{array}{l}\text { Leaders provide the vision } \\
\text { and a sound governance } \\
\text { structure }\end{array}$ \\
\hline
\end{tabular}




\subsection{Smart cities: A vision for development from water perspective, India}

"Cities in the past were built on riverbanks, now they are built along highways. But in the future, they will be built based on availability of optical fiber networks and nextgeneration infrastructure.” Mr. Narendra Modi

The 100 number of Smart Cities program declared by Govt. of India is to make cities smart in all respect. In Smart Cities, every citizen ensures quality of life along with all basic amenities and facilities. Economic social and environmental sustainability is the main agenda of development (20). The concept of smart city varies from one place to another. It depends on the level of development, willingness to change and reform, resources and aspirations of the city residents. The smart city should provide a clean and sustainable development considering the aspects of social, economic and environmental sustainability.

A smart city should be able to provide a better Quality of Life to its citizens, which includes safety and security for women, children and the elderly, inclusiveness, entertainment, access to public Utilities, cost efficient healthcare, quality education, transparency, accountability and opportunities for participation in governance (20).

\subsection{Indian water scenario}

In 2000, International Water Management Institute published, one survey of projected water scarcity in 2025 worldwide, which says more than $85 \%$ India, will be water scarce as the population is more than 125 million today (21). $4 \%$ water available for $17 \%$ world's population. Unavailability of water, overuse and exploitation of water resources create trouble to people as water is life, without which survival is impossible. In Indian context the crisis of water is viewed as crisis of availability of water.

In urban India, Urban water management is a significant challenge in front of govt. authorities, as due to unavailability of water and sanitation infrastructure, waste water is often laid in open drains leading to unhygienic condition and environmental pollution of rivers and streams. Public officials believe that environmental problems are solved by rules and regulations. Storm water rules and regulations in India, are borrowed from USA/ EU and not tailored to fit the local environment.

\subsection{The current water paradigm in India}

The current paradigm of treating all forms of rainwater, storm water, ground water and wastewater separately leading to polluted water bodies in most of the cities. Mithi river at Mumbai, Musi river at Hyderabad, GangaYamuna at North India, Panchganga, Krishna and Jayanti at Kolhapur and so many other rivers in India, most of them are polluted and water is not safe for drinking purpose as per C.P.C.B. (Central Pollution Control Board, India) (3). This The recent fifth paradigm of sustainable urban water management (all forms of water like rainwater, storm water, ground water, wastewater) supports the importance of river ecosystems and agrees rivers are the lifelines of cities. In this paradigm micro level green infrastructure linked to macro level water shed management to balance urban hydrological cycle. To deliver sustainable urban water five major aspects like, resilient vision, urban water governance, knowledge capacities, planning tools and implementation tools as explained in Table No. 3. (3).

Table 3 Five building blocks to deliver sustainable urban water (8)

\begin{tabular}{|c|c|c|c|c|}
\hline Vision & Governance & Knowledge/ Capacities & Planning Tools & $\begin{array}{l}\text { Implementation } \\
\text { Tools }\end{array}$ \\
\hline $\begin{array}{l}\text { Resilient city vision } \\
\text { enables people to } \\
\text { work together for } \\
\text { greater benefit of } \\
\text { urban community. }\end{array}$ & $\begin{array}{l}\text { Governance and } \\
\text { institutions provide } \\
\text { the framework for } \\
\text { urban stakeholders } \\
\text { to work together }\end{array}$ & $\begin{array}{l}\text { Urban stakeholders } \\
\text { have knowledge and } \\
\text { capacities at different } \\
\text { scales within the city. }\end{array}$ & $\begin{array}{lr}\text { Asset management, } \\
\text { master r plans } \\
\text { decision support } \\
\text { systems to initiate } \\
\text { action. }\end{array}$ & $\begin{array}{l}\text { Regulations based on } \\
\text { quality assurance, } \\
\text { transparency, } \\
\text { accountability }\end{array}$ \\
\hline $\begin{array}{l}\text { A shared vision } \\
\text { implementation } \\
\text { new policies }\end{array}$ & $\begin{array}{l}\text { Intégration water in } \\
\text { the city services and } \\
\text { design. }\end{array}$ & $\begin{array}{l}\text { Through a sustainable } \\
\text { water "vision" }\end{array}$ & $\begin{array}{l}\text { identifying benefits } \\
\text { and co- benefits of } \\
\text { projects, }\end{array}$ & $\begin{array}{l}\text { Financing tools to } \\
\text { adopt more efficient } \\
\text { solutions }\end{array}$ \\
\hline $\begin{array}{l}\text { A sustainable urban } \\
\text { water vision }\end{array}$ & $\begin{array}{l}\text { incentives for urban } \\
\text { stakeholders }\end{array}$ & $\begin{array}{l}\text { sustainable urban water } \\
\text { successes, }\end{array}$ & $\begin{array}{l}\text { defining levels of } \\
\text { service }\end{array}$ & $\begin{array}{l}\text { circular economy } \\
\text { mechanisms, }\end{array}$ \\
\hline $\begin{array}{lr}\text { It } & \text { provides } \\
\text { consistency } & \text { beyond } \\
\text { political cycles. }\end{array}$ & $\begin{array}{l}\text { Maximizing the } \\
\text { benefits of water to } \\
\text { cities. }\end{array}$ & $\begin{array}{l}\text { The ability to pool } \\
\text { resources, share tools }\end{array}$ & $\begin{array}{l}\text { ensuring ownership } \\
\text { by stakeholders }\end{array}$ & $\begin{array}{lr}\text { Integrated } & \text { services } \\
\text { with } & \text { investment } \\
\text { cycle, } & \end{array}$ \\
\hline
\end{tabular}


It is also very often economically viable, even under prevailing economic models, provided that the multiple services and all their associated benefits for the large number of beneficiaries in cities are properly quantified and recognized. Such information is essential to include in decision-making processes related to land use and management in urban landscapes, and to help guide urban and landscape planners, architects, restoration practitioners, and public policy makers, as well as private and institutional stakeholders.

\section{Results and recommendations}

Always there are tensions between preservation and management, nature and culture, tradition and technology, theory and practice. Prolonged and immediate effect of population explosion and unprecedented urbanization decision makers always faces new challenges to provide all basic infrastructure services and to connect them at city level basic planning, management, implementation and monitoring of all water systems. The challenges may resemble same wherever you go, throughout India, irrespective of different cultures, politics, institutional frameworks etc.

As rivers are lifelines of the cities, new paradigm of sustainable water centric eco-cities are based entirely on role of watercondition inside the cities. The urban ecoregion concept is depending upon sustainability of urban water cycle. The wastewater (gray water, black water) management and solid waste management and the prime most parts of city functioning and cannot be neglected for River's ecological health (2). While thinking of a development paradigm form cities resilience point of view, it is important to fill the gaps of knowledge fields like urban design, urban planning, sociology and ecology. Urban nexus of water - food-energy is always depending upon what kind of human and nature relationship persistent at city level. Recent rapid expansion of urban areas on one side putting tremendous pressure on environment and eco systems, but on the other side providing fundamental challenges and opportunities to design more water sensitive eco-cities (2), as per table 4 .

Table 4 :- Sustainable water centric eco-cities (2)

\begin{tabular}{|l|l|}
\hline Water & The focus of sustainable cities movement \\
\hline Micro scale & Green buildings. \\
\hline Subdivision & Eco-blocks \\
\hline Macro scale & Eco-cities and ecologically engineered urban water sheds. \\
\hline Urban-eco & Region concept, Sustainable urban water cycle. \\
\hline Waste water & $\begin{array}{l}\text { Used water provides energy in the form of electricity, biogas, hydrogen, fertilizer, raw materials for } \\
\text { reuse and heat. Used water, Reclaimed water, Resource recovery }\end{array}$ \\
\hline hybrid & Partially decentralized or fully decentralized water/storm water/used water system \\
\hline
\end{tabular}

\section{Conclusion}

Geographer Matthew Gandy writes - "Water is not simply material element in the production of cities but is also a critical dimension in the social production of space."

The calls for "Water centric sustainable communities," "Cities of the Future," "Sustainable bluegreen urbanism" may sound today more like futuristic dreams than a potential reality (2). But the future is always an extension of history and change is forced, and guided, by new incremental discoveries and stresses. To solve multi-aspect problem, multi-disciplinary rather trans- disciplinary research is absolute necessary (2). The time has come to look for and implement new concepts for urban planning and landscape design. In the "Cities of the Future" context, one has to look to, and learn from, the past about the importance of water in cities (2). Resilient cities able to manage all the consequences and ill effects of rapid urbanization and industrialization also bring many new opportunities in front of future urban planners. Water sensitive sustainable cities based on low impact development strategies also promotes social interaction and green economy along with ecological restoration of rivers.

This research was supported by Visvesvaraya Technological University, Jnana Sangama, and Belagavi 590018 for Grant of financial assistance.

\section{References}

1. J. Anthony. "The urban environment and health in a world." Bulletin of the World Health Organization. Vol. 78 (9) (2000).

2. V. Novotny. WATER CENTRIC. United States of America: JOHN WILEY \& SONS, INC. ISBN 978-0470-47608-6 (cloth); ISBN 978-0-470-64282-5 (ebk); ISBN 978-0-470-64283-2 (ebk);(2010)

3. V. Novotny. A New Paradigm of Sustainable Urban Drainage and Water. Oxford University: Oxford Roundtable Workshop on Sustainability, (2008).

4. Paris statement. United Nations, (2007).

5. Metadata on Suggested Indicators for Global Monitoring. UN-Water(2016).

6. Consolidated Technical Input from UN Agencies. (2015). 
7. E. Rietveld. Improving health in cities through systems. Manchester, UK : Environmental Health (2016). 8. Principles for urban stakeholders to develop a shared vision and act towards sustainable urban water in resilient and liveable cities. The IWA.

9. D. Satterthwaite, S. Huq, M. Pelling, A. Reid, Romero. Adapting to climate change in. London (UK) : Human Settlements Discussion Paper Series -, (2007).

10. C. Folke. Resilience: the emergence of a perspective for social-ecological.Global Environmental Change, Vols. 16 (3), pp. 253-267. (2006)

11. G. Barnett, X. Bai. Urban resilience research. Stockholm : Stockholm University, (2007).

12. T. Elmqvist, H. Setala, S. Handel, S. Ploeg, B. Elsevier. Benefits of restoring ecosystem services in urban areas., Current Opinion in Environmental Sustainability, Vol. 14, pp. 101-108, 22nd May (2015). 13. D. Koutsoyiannis, N. Zarkadoulas, A. Angelakis, G Tchobanoglous. Urban : Water, Vol. 134, pp. 45-54 (2008).

14. D . Grey, C . Sadoff. Sink or Swim? Water security for growth and Water Policy. Vol.9, pp 545 (2007).

15. C. Vörösmarty, J. Hoekstra, S. Bunn , D . Conway, and J. Gupta, Fresh water goes global. Vol. Science 349, pp. 478-479.

16. Achieving Sustainable Development. A. Bhaduri, J . Bogardi, A . Siddiqi, Front. Environ.Sci, Vol. 4, pp. 64. (2016),

17. Theunitednationsworldwaterdevelopmentreport: S.1. : UNESCO-WWAP, (2015).

18. Principles for urban stakeholders to develop a shared vision and act towards sustainable urban water in resilient and liveable cities. THE IWA.

19. S. Pickett, M. Cadenasso. "Linking ecological and built components of urban mosaics: an open cycle of ecological design.". Journal of Ecology, , Vol. 96(1), pp. Pp. 8-12 (2008).

20.V.Upadhyaya , Smart Cities: A Vision for Development of Indian Cities, Imperial Journal of Interdisciplinary Research (IJIR), Vol. 2. ISSN: 24541362. (2016)

21. Water scarcity. S.1. : International water management institute, (2000).

22. D. Schaffer, D. Vollmer. Pathways to urban sustainability, Washington D.C : National Academies Press. 